\title{
Intramyocardial gene transfer of vascular endothelial growth factor 121 improves myocardial perfusion and function in the ischemic porcine heart
}

Ariana G. Ojalvo*

Centro de Ingeniería Genética y Biotecnología

Ave. 31 e/ 158 y 190

Cubanacán, Playa

P.O. Box 6162

La Habana 10600, Cuba

Tel: 5372716022

Fax: 5372714764

E-mail: ariana.garcia@cigb.edu.cu

Alina Seralena

Centro de Ingeniería Genética y Biotecnología

Ave. 31 e/ 158 y 190

Cubanacán, Playa

P.O. Box 6162

La Habana 10600, Cuba

Tel: 5372716022

Fax: 5372714764

E-mail: alina.seralena@cigb.edu.cu

Nelson S. Vispo

Centro de Ingeniería Genética y Biotecnología

Ave. 31 e/ 158 y 190

Cubanacán, Playa

P.O. Box 6162

La Habana 10600, Cuba

Tel: 5372716022

Fax: 5372714764

E-mail: nelson.santiago@cigb.edu.cu

Ricardo Silva

Centro de Ingeniería Genética y Biotecnología

Ave. 31 e/ 158 y 190

Cubanacán, Playa

P.O. Box 6162

La Habana 10600, Cuba

Tel: 5372716022

Fax: 5372714764

E-mail: ricardo.silva@cigb.edu.cu

\section{Noel Gonzalez}

Departamento de Cirugía Cardiovascular

Hospital "Hermanos Ameijeiras"

San Lázaro 701, Centro Habana

La Habana, Cuba

Tel: 5378776021

E-mail: nglez@infomed.sld.cu

Luis Guevara

Departamento de Cirugía Cardiovascular

Hospital "Hermanos Ameijeiras"

San Lázaro 701, Centro Habana

La Habana, Cuba

Tel: 5378776021

E-mail: lguevara@infomed.sld.cu

Juan F. Batista

Centro de Investigaciones Clínicas

Calle 34 No. 4501 e/ 45 y 47

Kohly, Playa, P.O. Box 11300

$$
\text { La Habana, Cuba }
$$


Tel: 5372043298

Fax: 5372043298

E-mail: batista@infomed.sld.cu

Jose F. Montequin

Instituto de Angiología y Cirugía Vascular

Hospital "Salvador Allende"

Calzada del Cerro 1551, Cerro, La Habana, Cuba

Tel: 5378776493

E-mail: montequi@infomed.sld.cu

\section{Nicolas Chaos}

Departamento de Cirugía Cardiovascular

Hospital "Hermanos Ameijeiras"

San Lázaro 701, Centro Habana

La Habana, Cuba

Tel: 5378776021

E-mail: nchaosglez@yahoo.com

\section{Rafael González}

Departamento de Cirugía Cardiovascular

Hospital "Hermanos Ameijeiras"

San Lázaro 701, Centro Habana

La Habana, Cuba

Tel: 5378776021

E-mail: ccardio@hha.sld.cu

\section{Camilo Reima}

Departamento de Cirugía Cardiovascular

Hospital "Hermanos Ameijeiras"

San Lázaro 701, Centro Habana

La Habana, Cuba

Tel: 5378776021

E-mail: ccardio@hha.sld.cu

\section{Yamile Peña}

Centro de Investigaciones Clínicas

Calle 34 No. 4501 e/ 45 y 47

Kohly, Playa, P.O. Box 11300

La Habana, Cuba

Tel: 5372043298

Fax: 5372043298

E-mail: yamilepq@infomed.sld.cu

\section{Marcos Coca}

Centro de Investigaciones Clínicas

Calle 34 No. 4501 e/ 45 y 47

Kohly, Playa, P.O. Box 11300

La Habana, Cuba

Tel: 5372043298

Fax: 5372043298

E-mail: mcoca@infomed.sld.cu

\section{Alejandro Perera}

Centro de Investigaciones Clínicas

Calle 34 No. 4501 e/ 45 y 47

Kohly, Playa, P.O. Box 11300

La Habana, Cuba

Tel: 5372043298

Fax: 5372043298

E-mail: alejandro.perera@infomed.sld.cu

\section{Raysa Vazquez}

Centro de Ingeniería Genética y Biotecnología

Ave. 31 e/ 158 y 190

Cubanacán, Playa

P.O. Box 6162

La Habana 10600, Cuba

Tel: 5372716022 
Fax: 5372714764

E-mail: raysa.vazquez@cigb.edu.cu

Yaquelin Puchades

Centro de Ingeniería Genética y Biotecnología

Ave. 31 e/ 158 y 190

Cubanacán, Playa

P.O. Box 6162

La Habana 10600, Cuba

Tel: 5372716022

Fax: 5372714764

E-mail: yaquelin.puchades@cigb.edu.cu

\section{Tamara Garcia-Osuna}

Instituto de Investigaciones Porcinas

Carretera del Guatao km 1

Punta Brava, La Habana, Cuba

Tel: 5372099125

E-mail: iip00@ceniai.inf.cu

\section{Heberto Dominguez}

Instituto de Investigaciones Porcinas

Carretera del Guatao km 1

Punta Brava, La Habana, Cuba

Tel: 5372099125

E-mail: iip00@ceniai.inf.cu

\section{Jose L. Reyes}

Instituto de Investigaciones Porcinas

Carretera del Guatao km 1

Punta Brava, La Habana, Cuba

Tel: 5372099125

E-mail: iip00@ceniai.inf.cu

\section{Alfonso Ali}

Centro de Ingeniería Genética y Biotecnología

Ave. 31 e/ 158 y 190

Cubanacán, Playa

P.O. Box 6162

La Habana 10600, Cuba

Tel: 5372716022

Fax: 5372714764

E-mail: alfonso.ali@cigb.edu.cu

\section{Luis Herrera}

Centro de Ingeniería Genética y Biotecnología

Ave. 31 e/ 158 y 190

Cubanacán, Playa

P.O. Box 6162

La Habana 10600, Cuba

Tel: 5372716022

Fax: 5372714764

E-mail: luis.herrera@cigb.edu.cu

URL: http://www.cigb.edu.cu/

Financial support: This work has been supported by the Center for Genetic Engineering and Biotechnology, Havana, Cuba.

Keywords: collateral development, coronary artery disease, gene therapy, naked plasmid DNA, revascularization, therapeutic angiogenesis.

Abbreviations: ANOVA: analysis of variance

Gated-SPECT: single photon emission computed tomography-electrocardiogram coupled

LVEF: left ventricular ejection fraction

SD: standard deviation

VEGF: vascular endothelial growth factor.

\footnotetext{
* Corresponding author
} 
Vascular endothelial growth factor (VEGF) is an endothelial cell-specific mitogen that is angiogenic in vitro and in vivo. Several studies report on gene transfer of VEGF $_{121}$ to promote angiogenesis in the ischemic myocardium of animals and patients. We hypothesized that intramyocardial administration of naked plasmid DNA encoding VEGF 121 $_{12}$ could improve myocardial perfusion and function in a porcine model of myocardial ischemia. Yorkshire swine underwent thoracotomy and placement of an ameroid constrictor on the circumflex coronary artery. Four weeks later, pVEGF $_{121}$ plasmid was administered into the ischemic myocardium. Four weeks after gene transfer, SPECT imaging demonstrated significant reduction in the ischemic area in PVEGF $_{121}$-treated animals compared with controls. In the pVEGF $_{121}$ group, most of the animals evolved from light ischemia to a normal perfusion. In contrast, control animals exhibited similar or impaired ischemic conditions. Our results indicate that intramyocardial gene transfer of VEGF $_{121}$ as naked plasmid DNA results in significant improvement in myocardial perfusion and function.

Coronary heart disease is a major cause of mortality and morbidity in humans. Present treatments include pharmacological therapy, followed by percutaneous transluminal coronary angioplasty or coronary artery bypass graft surgery. Although these treatments are often helpful, restenosis of coronary vessels occurs in $30-35 \%$ of the patients (Libby et al. 1992). On the other hand, there is a significant group of patients who have diffuse coronary artery disease, or have had multiple previous interventions. In these cases, angioplasty or bypass may not be feasible because of poor target vessels, lack of conduits, or unacceptable operative risk. Despite maximal pharmacological therapy, many of these patients remain incapacitated by frequent anginal attacks. Therefore, alternative treatments are needed.

Therapeutic angiogenesis has emerged as a potential alternative approach for treating ischemic disorders such as peripheral vascular and coronary artery diseases. In therapeutic angiogenesis exogenous angiogenic growth factors (or genes encoding these growth factors) are used to stimulate the growth of collateral vessels to ischemic tissues.

One of the most widely studied angiogenic growth factors is vascular endothelial growth factor (VEGF), a homodimeric heparin-binding glycoprotein of 34-46 kDa (Leung et al. 1989). Administration of recombinant VEGF has been shown to improve collateral blood flow to the ischemic myocardium in animal models (Hariawala et al. 1996; Lopez et al. 1998), as well as in patients with coronary artery disease (Hendel et al. 2000; Henry et al. 2001).

Genes encoding VEGF have also been successfully delivered to ischemic tissues. Several studies report on adenovirus-mediated gene transfer of the 121-amino acid isoform of VEGF $\left(\mathrm{VEGF}_{121}\right)$ to promote angiogenesis in the ischemic myocardium of animals (Patel et al. 1999; Lee et al. 2000) and patients (Rosengart et al. 1999a; Rosengart et al. 1999b). However, virus administration can lead to undesired immune responses (Epstein et al. 2001).

The use of naked plasmid DNA obviates these immunological concerns and simplifies the transfection protocol. Preclinical (Tio et al. 1999) and clinical studies (Symes et al. 1999; Vale et al. 2000) document that gene transfer of naked plasmid DNA encoding VEGF $_{165}$ promotes collateral vessel development in the ischemic myocardium. The same approach has been used by our group to deliver $\mathrm{VEGF}_{121}$ gene to the limbs of dogs with surgically induced hindlimb ischemia (Ojalvo et al. 2003). In the present study, we hypothesized that intramyocardial administration of naked plasmid DNA encoding VEGF $_{121}$ could improve myocardial perfusion and function in a porcine model of myocardial ischemia.

\section{MATERIALS AND METHODS}

\section{pVEGF $_{121}$ plasmid DNA}

pVEGF $_{121}$ plasmid (Ojalvo et al. 2003) contains the DNA sequence encoding human VEGF121 under control of the immediate-early promoter/enhancer from the human cytomegalovirus. Plasmid DNA was purified from cultures of pVEGF121-transformed E. coli DH10B as previously described (Ojalvo et al. 2003).

\section{Animal model}

Yorkshire swine with surgically induced myocardial ischemia were used for the experiments. All protocols were approved by the Institutional Animal Care and Use Committee and were conducted in accordance with the Health Guide for the Care and Use of Laboratory Animals. Induction of chronic myocardial ischemia was performed by placement of an ameroid constrictor around the left circumflex coronary artery, essentially as described (Harada et al. 1994). Nine female swine, weighing 25-30 $\mathrm{kg}$, were anesthetized with intramuscular flunitrazepan (0.1 $\mathrm{mg} / \mathrm{kg})$, ketamine $(1.5 \mathrm{mg} / \mathrm{kg})$; and then with intravenous flunitrazepan $(0.2 \mathrm{mg} / \mathrm{kg})$, ketamine $(1.5 \mathrm{mg} / \mathrm{kg})$ and succinilcoline (1 mg). Animals were intubated and mechanically ventilated. By sterile technique, a left thoracotomy of 10-12 cm was performed through the fourth intercostal space. The pericardium was opened and the 
pVEGF $_{121}$
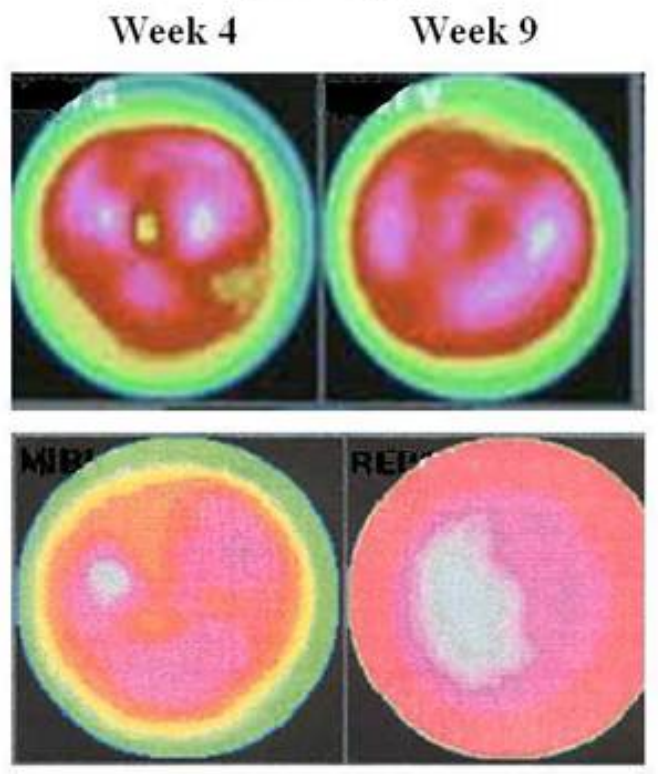

\section{Control}
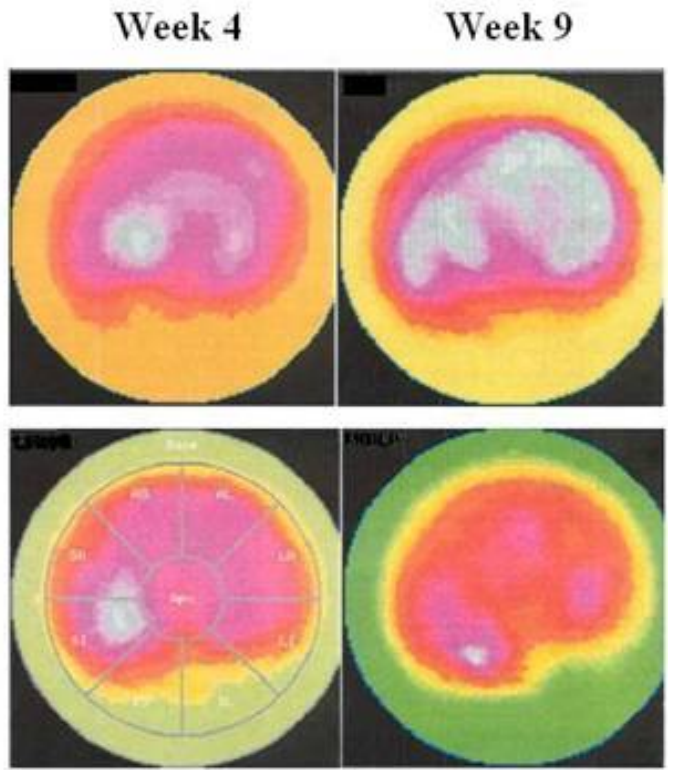

\section{Non ischemic control}

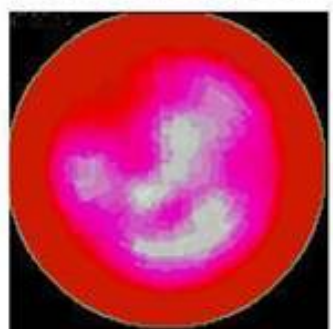

Figure 1. SPECT images of animals before (Week 4) and after (Week 9) treatment with pVEGF 121 or saline. Non ischemic control corresponds to the first gammagraphic study (week 0). White, pink and red colours indicate normal perfusion. Brown, yellow and green denote defective perfusion.

circumflex coronary artery was disected free. An ameroid constrictor (Research Instruments MFG, Corvallis, Ore.) of $1.5 \mathrm{~mm}$ was placed at the main trunk of the circumflex artery, with no involvement of the marginal branches. Then, the thoracotomy was closed. Intramuscular penicillin ( $2 \times 10^{6} \mathrm{U} /$ day, during 7 days) and intravenous B complex vitamins were administered for prophylaxis.

\section{Intramyocardial gene transfer}

Four weeks after induction of ischemia, animals underwent repeat thoracotomy and received intramyocardial injections of either $\mathrm{pVEGF}_{121}$ plasmid $(\mathrm{n}=5)$ or saline $(\mathrm{n}=4)$, using 1 $\mathrm{mL}$ syringes and $26 \mathrm{G}$ needles. Injections were performed at 4 different sites in the ischemic areas (previously located by SPECT imaging) at a $5 \mathrm{~mm}$ depth. Each pig received a $500 \mu \mathrm{g}$ dose, divided in four $125 \mu \mathrm{g} / 0.25 \mathrm{~mL}$ injections. Saline $(0.9 \% \mathrm{NaCl})$ was administered in the same way as pVEGF $_{121}$ (four $0.25 \mathrm{~mL}$ injections). Pre- and postoperatory procedures were performed as described above (see Animal model).

\section{Gated-SPECT imaging}

Gammagraphic studies were performed at the beginning of the protocol (week 0), 3 weeks after induction of ischemia (week 4), and 4 weeks after gene transfer (week 9). Gated Myocardial Perfusion SPECT images were acquired $1 \mathrm{~h}$ after intravenous infusion of 1073-1295 MBq (29-35 mCi) of ${ }^{99 \mathrm{~m}}$ Tc-MIBI, using a gamma camera (Sophy DS-7, Sopha Medical Systems, France), equipped with a low-energy allpurpose parallel-hole collimator. Imaging was performed by using a $180^{\circ}$ circular orbit with 32 images of $50 \mathrm{sec}$ each, and a $20 \%$ window centered on the $140 \mathrm{keV}$ photopeak. Images were processed using the softwares MyoSpect and Emory Cardiac Toolbox version 1.1 in a workstation Power Vision (GE-SMV, Canada). The backprojection method was employed for image reconstruction using a Butterworth filter, order 5 and cutoff 0.36. No attenuation correction was used. Orthogonal 
tomographic slices of trans-axial, sagittal and coronal images were reconstructed using a 64 x 64 matrix. Myocardial perfusion was evaluated in terms of presence, number, extension, severity and topography of perfusion defects. Left ventricular myocardium was divided into 17 segments for visual interpretation of results. A region having two or more segment with deficit of perfusion (less than $70 \%$ of the maximum ${ }^{99 \mathrm{~m}}$ Tc-MIBI uptake value) was considered as a perfusion defect. Severity was graded according to the percentage with respect to the maximum ${ }^{99 \mathrm{~m}}$ Tc-MIBI uptake value as follows: light (60-69\%), moderate (50-59\%) and severe (less than 50\%).

\section{Statistical analysis}

For the analysis of the LVEF data, results were expressed as mean \pm SD. The Kolmogorov-Smirnov and Levene's tests were used to analyze normal distribution and variance homogeneity, respectively. Statistical significance of differences between groups was evaluated using an ANOVA. A value of $\mathrm{P}<0.05$ was interpreted to denote statistically significant differences.

\section{RESULTS AND DISCUSSION}

The present study reports on the successful gene transfer and expression of naked plasmid DNA expressing the 121amino acid isoform of VEGF in a porcine model of myocardial ischemia, with physiological evidence of improved myocardial perfusion and function.

Nine healthy swine, having normal perfusion/function patterns, underwent surgical induction of myocardial ischemia. We used the ameroid constrictor technique described by Harada and co-workers (Harada et al. 1994) to produce gradual (2-4 weeks) occlusion of the proximal circumflex coronary artery. This method allows for the development of a chronically ischemic region of the left ventricular myocardium that does not possess a pre-existing collateral blood supply. Three weeks later, myocardial perfusion and function were assessed by SPECT imaging. Light or moderate ischemic areas were localized in all animals (Table 1, Week 4). The variability observed on topography, extension and severity of induced ischemia could be related to the anatomic characteristics of the collapsed artery as well as its dominance with respect to the perfused muscular area.

Animals were treated with $\mathrm{pVEGF}_{121}$ or saline by intramyocardial injection through a second thoracotomy. Four weeks after treatment, most of $\mathrm{pVEGF}_{121}$-treated animals evolved to a normal perfusion (Table 1). In contrast, all control animals exhibited similar or impaired ischemic conditions. Representative SPECT images acquired from both $\mathrm{pVEGF}_{121}$ and control animals are shown in Figure 1. In pVEGF 121 group, an important reduction in the ischemic area was typically observed 4 weeks after gene transfer (week 9) when compared with baseline (week 4) (Figure 1, left). In contrast, control SPECT images showed persistent perfusion defects at week 9 (Figure 1, right).

Before gene transfer (week 4), mean values of ${ }^{99 \mathrm{~m}} \mathrm{Tc}$-MIBI uptake index were similar in both groups $\left(\mathrm{pVEGF}_{121}=54.7\right.$ $\pm 6.6 \%$, control $=53.7 \pm 7.4 \%$; $=\mathrm{NS}$ ) and lower than basal ${ }^{99 \mathrm{~m}}$ Tc-MIBI uptake index (> $80 \%$ in both groups). However, at week 9, pVEGF 121 -treated animals exhibited significantly higher ${ }^{99 \mathrm{~m}}$ Tc-MIBI uptake index compared with the control group $\left(\mathrm{pVEGF}_{121}=71.9 \pm 6.8 \%\right.$ versus control $=53.2 \pm 11.5 \%, \mathrm{P}<0.05)$ (Figure 2). These results provide evidence about a $35 \%$ improvement in myocardial function. These findings were more relevant in those pigs having bigger perfusion defects. No side effects could be associated to the administration of $\mathrm{pVEGF}_{121}$ plasmid.

pVEGF $_{121}$ plasmid has been previously evaluated by our group in a dog model of hindlimb ischemia (Ojalvo et al. 2003), providing evidence of increased collateral vessel development, and improvement in hemodynamic and physiological deficits induced by ischemia. Our present results correspond to and complement this previous study. Our findings are also in agreement with a previous work which reported the successful intramyocardial delivery of naked plasmid DNA encoding VEGF $_{165}$ in a similar model of myocardial ischemia (Tio et al. 1999). The promising results of this preclinical study have been further confirmed

Table 1. Characterization of myocardial perfusion.

\begin{tabular}{|c|c|c|c|c|}
\hline Treatment & Animal No. & Week 0 & Week 4 & Week 9 \\
\hline \multirow{4}{*}{ pVEGF $_{121}$} & 02 & Normal & Light antero-apical ischemia & Normal \\
\cline { 2 - 5 } & 05 & Normal & $\begin{array}{c}\text { Light apical ischemia } \\
\text { Light infero-lateral ischemia }\end{array}$ \\
\cline { 2 - 5 } & 09 & Normal & Moderate inferior ischemia & Very light inferior ischemia \\
\cline { 2 - 5 } & 11 & Normal & Light infero-lateral ischemia & Normal \\
\hline \multirow{4}{*}{ Control } & 17 & Normal & Light infero-lateral ischemia & Normal \\
\cline { 2 - 5 } & 08 & Normal & Moderate infero-lateral ischemia & Moderate infero-lateral ischemia \\
\cline { 2 - 5 } & 16 & Normal & Moderate inferior ischemia & Moderate inferior ischemia \\
\cline { 2 - 5 } & 20 & Normal & Light infero-lateral ischemia & Light infero-lateral ischemia \\
\hline
\end{tabular}


by clinical trials (Symes et al. 1999; Vale et al. 2000). However, VEGF 165 gene transfer has failed to improve neovascularization or regional myocardial blood flow in a rat myocardial infarction model (Kloner et al. 2000; Schwarz et al. 2000).

Adenovirus-mediated gene transfer of $\mathrm{VEGF}_{121}$ has been used to promote angiogenesis in the ischemic myocardium of animals (Patel et al. 1999; Lee et al. 2000), and patients (Rosengart et al. 1999a; Rosengart et al. 1999b). Adenoviral vectors are $10^{3}$ - to $10^{4}$ - fold more efficient in vivo (per transgene) at transfecting target cells than plasmid systems (Crystal, 1995). However, the administration of large amounts of virus can lead to massive immune responses that could cause serious, even fatal, immunopathology. The anti-adenoviral vector response in humans is strikingly dependent on the pre-existing antiadenovirus neutralizing antibody titer (Harvey et al. 1999), likely due to prior exposure to wild-type adenovirus of a similar serotype. Neutralizing anti-adenovirus antibodies may significantly reduce the efficiency of gene transfer. Therefore, repeated administration of the recombinant adenovirus is typically ineffective. This anti-adenoviral vector response could also mediate destruction of transfected cells, liver and myocardial inflammation (Epstein et al. 2001). In fact, numerous gene therapy clinical trials have been interrupted by the Food and Drug Administration in the wake of the death of an 18-year-old subject enrolled in a study of ornithine transcarbamylase deficiency involving adenoviral gene therapy (Lehrman, 1999).

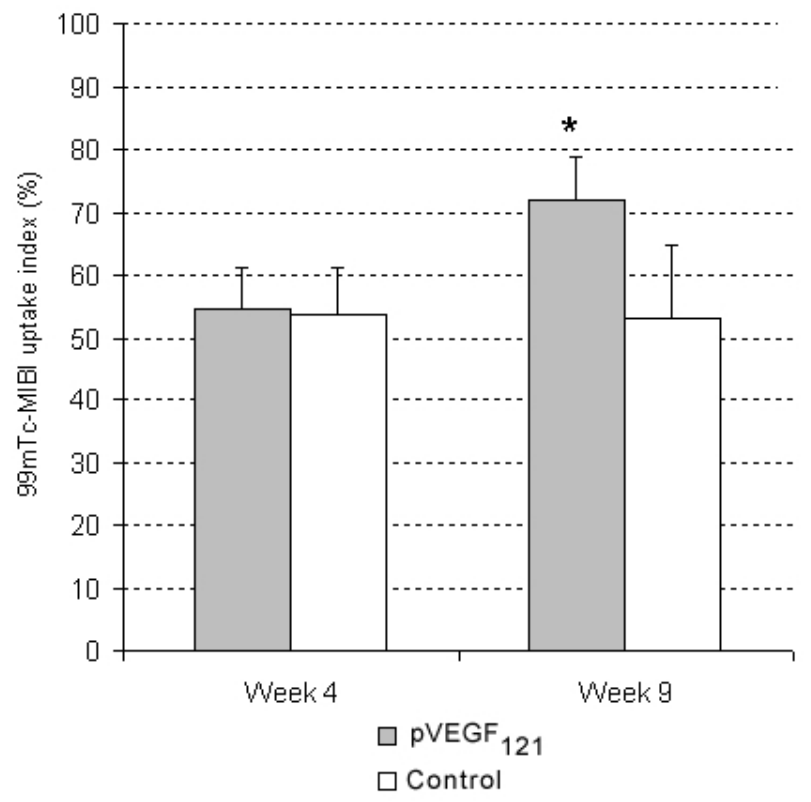

Figure 2. Effect of intramyocardial VEGF $_{121}$ gene transfer on myocardial function, as assessed by $99 \mathrm{mTC}-\mathrm{MIBI}$ uptake index in the ischemic area.

* $P<\cap 05$ versiıs rentrol
In contrast, no evidence of an immune response has been recognized in animal experiments using naked plasmid DNA (Nabel et al. 1993). DNA is subsequently denatured and is likely to be removed by the reticuloendothelial system. The limiting factor associated with the use of naked DNA for intramyocardial gene transfer has been its low transfection efficiency. However, features of the gene, protein, and target tissue may all contribute to phenotypic modulation of the host despite a low transfection efficiency. Fist, VEGF contains at its amino terminus the signal sequence which permits it to be actively secreted by intact cells, and to exert paracrine effects. It has been previously shown that genes encoding proteins that are naturally secreted, such as VEGF, can achieve meaningful biological outcomes despite low transfection efficiency (Losordo et al. 1994).

Second, VEGF is endothelial cell specific because its receptors Flt-1 and Flk-1/KDR are restricted to endothelial cells (Neufeld et al. 1999). Therefore, all the VEGF activity is focused on the critical cellular element responsible for new vessel formation. Moreover, the ischemic environment of the transfected muscle induces VEGF expression in endothelial cells and upregulates VEGF receptors on the cell surface (Brogi et al. 1996). Thus, endothelial cell proliferation in the ischemic territory creates additional potential sites of VEGF synthesis and secretion, amplifying the effects of even a small amount of exogenous VEGF.

Third, myocardium has been shown to take up DNA more efficiently than other tissue types. It has been reported that gene injection into the rat heart results in gene expression levels up to 50-fold higher than similar experiments in skeletal muscle (Buttrick et al. 1992). In addition, hypoxic muscle has been shown to exhibit a more than five-fold increased uptake and expression of exogenous plasmid DNA compared with normal muscle (Takeshita et al. 1996a).

Finally, VEGF inhibits apoptosis (Asahara et al. 1996), and mediates an increase in circulating endothelial progenitor cells after VEGF gene transfer (Kalka et al. 2000). Such effects would be expected to complement the mitogenic action of VEGF, resulting in a further net increase in endothelial cell viability.

When considering safety of VEGF gene transfer and expression, pathological angiogenesis is the main concern. Pathological angiogenesis is thought to play a part in several diseases, including tumour growth, diabetic proliferative retinopathy, macular degeneration, rheumatoid pannus formation, and progression of atherosclerosis (Henry, 1999). In this regard, a localized and transient gene expression assures that the recipient is not indefinitely exposed to increased levels of VEGF. Transient expression of VEGF gene in transfected myocardium, as well as focal 
angiogenic response have been documented (Lee et al. 2000). In our previous work, no modifications were found in an important set of hematological variables as a result of VEGF $_{121}$ gene transfer (Ojalvo et al. 2003). No side effects could be associated to the administration of $\mathrm{pVEGF}_{121}$ plasmid in both the former and the present studies.

The surgical procedure required for intramyocardial gene transfer is another important concern when considering clinical application. The feasibility, safety, and efficacy of catheter-based transendocardial delivery of VEGF genes to the human heart has recently been shown (Vale et al. 2001; Losordo et al. 2002), demonstrating that direct myocardial gene transfer can be accomplished without the need of thoracotomy.

The VEGF transcript is normally spliced into five different isoforms having 121, 145, 165, 189, and 206 amino acids, respectively (Neufeld et al. 1999). The 121, 165, and 189 isoforms are the predominant forms in most VEGFproducing cell types. The heparin binding ability and the secretion pattern of the five isoforms differ markedly. VEGF $_{121}$ is a weakly acidic polypeptide that does not bind to heparin, and is freely soluble in the conditioned medium of transfected cells. The heparin-binding capabilities of the remaining isoforms are progressively augmented as a result of a step-wise enrichment in basic residues. Thus, VEGF 165 is a basic heparin-binding glycoprotein; while secreted, a significant portion remains bound to the cell surface or the extracellular matrix. $\mathrm{VEGF}_{189}$ is not secreted into the cellular medium; it is sequestered on heparan-sulfate proteoglycans of cell surfaces and in the extracellular matrix. Proteases such as plasmin can cleave $\mathrm{VEGF}_{165}$ and VEGF $_{189}$ and release active soluble proteolytic fragments having a size similar to or smaller than the intact 121 isoform (Houck et al. 1992; Plouet et al. 1997). It has been speculated that these $\mathrm{VEGF}_{121}$-like molecules are the final common mediators of angiogenesis. This has been supported by the demonstration of biologic equivalence among 121, 165, and 189 VEGF isoforms for in vivo angiogenesis in a rabbit model of hindlimb ischemia (Takeshita et al. 1996b).

Previous works on VEGF gene transfer to the ischemic heart have used the 121- and 165-amino acid isoforms. $\mathrm{VEGF}_{121}$ gene transfer has been performed by means of adenoviral vectors (Patel et al. 1999; Rosengart et al. 1999a; Rosengart et al. 1999b; Lee et al. 2000). In contrast, naked plasmid DNA approach has been used for delivering VEGF $_{165}$ gene (Symes et al. 1999; Tio et al. 1999; Vale et al. 2000). This is the first study reporting on intramyocardial gene transfer of the 121-amino acid isoform of VEGF as naked plasmid DNA in a porcine model of myocardial ischemia.

The present study demonstrates that intramyocardial injection of $\mathrm{pVEGF}_{121}$ plasmid DNA results in sufficient VEGF $_{121}$ expression to significantly improve myocardial perfusion and function in a porcine model of myocardial ischemia. Such a strategy may be feasible in patients with ischemic heart disease who are not candidate to conventional revascularization procedures.

\section{ACKNOWLEDGMENTS}

We thank Dr. Pedro Lopez-Saura for helpful discussions about the experiments.

\section{REFERENCES}

ASAHARA, T.; TSURUMI, Y.; TAKESHITA, S. and ISNER, J.M. Naked cDNA encoding secreted proteins for intra-arterial and intramuscular gene transfer. Seminars in Interventional Cardiology, September 1996, vol. 1, no. 3, p. 225-232.

BROGI, E.; SCHATTEMAN, G.; WU, T.; KIM, E.A.; VARTICOVSKI, L.; KEYT, B. and ISNER, J.M. Hypoxiainduced paracrine regulation of vascular endothelial growth factor receptor expression. Journal of Clinical Investigation, January 1996, vol. 97, no. 2, p. 469-476.

BUTTRICK, P.M.; KASS, A.; KITSIS, R.N.; KAPLAN, M.L. and LEINWAND, L.A. Behavior of genes directly injected into the rat heart in vivo. Circulation Research, January 1992, vol. 70, no. 1, p. 193-198.

CRYSTAL, R.G. Transfer of genes to humans: early lessons and obstacles to success. Science, October 1995, vol. 270, no. 5235, p. 404-410.

EPSTEIN, S.E.; FUCHS, S.; ZHOU, Y.F.; BAFFOUR, R. and KORNOWSKI, R. Therapeutic interventions for enhancing collateral development by administration of growth factors: basic principles, early results and potential hazards. Cardiovascular Research, February 2001, vol. 49, no. 3, p. 532-542.

HARADA, K.; GROSSMAN, W.; FRIEDMAN, M.; EDELMAN, E.R.; PRASAD, P.V.; KEIGHLEY, C.S.; MANNING, W.J.; SELLKE, F.W. and SIMONS, M. Basic fibroblast growth factor improves myocardial function in chronically ischemic porcine hearts. Journal of Clinical Investigation, August 1994, vol. 94, no. 2, p. 623-630.

HARIAWALA, M.D.; HOROWITZ, J.R.; ESAKOF, D.; SHERIFF, D.D.; WALTER, D.H.; KEYT, B.; ISNER, J.M. and SYMES J.F. VEGF improves myocardial blood flow but produces EDRF-mediated hypotension in porcine hearts. Journal of Surgical Research, June 1996, vol. 63, no. 1 , p. 77-82. 
HARVEY, B.G.; HACKETT, N.R.; EL-SAWY, T.; ROSENGART, T.K.; HIRSCHOWITZ, E.A.; LIEBERMAN, M.D.; LESSER, M.L. and CRYSTAL, R.G. Variability of human systemic humoral immune responses to adenovirus gene transfer vectors administered to different organs. Journal of Virology, August 1999, vol. 73, no. 8, p. 6729-6742.

HENDEL, R.C.; HENRY, T.D.; ROCHA-SINGH, K.; ISNER, J.M.; KEREIAKES, D.J.; GIORDANO, F.J.; SIMONS, M. and BONOW, R.O. Effect of intracoronary recombinant human vascular endothelial growth factor on myocardial perfusion: evidence for a dose-dependent effect. Circulation, January 2000, vol. 101, no. 2, p. 118-121.

HENRY, T.D.; ROCHA-SINGH, K.; ISNER, J.M.; KEREIAKES, D.J.; GIORDANO, F.J.; SIMONS, M.; LOSORDO, D.W.; HENDEL, R.C.; BONOW, R.O.; EPPLER, S.M.; ZIONCHECK, T.F.; HOLMGREN, E.B. and MCCLUSKEY, E.R. Intracoronary administration of recombinant human vascular endothelial growth factor to patients with coronary artery disease. American Heart Journal, November 2001, vol. 142, no. 5, p. 872-880.

HENRY, T.D. Therapeutic angiogenesis. BMJ, June 1999, vol. 318, no. 7197, p. 1536-1539.

HOUCK, K.A.; LEUNG, D.W.; ROWLAND, A.M.; WINER, J. and FERRARA, N. Dual regulation of vascular endothelial growth factor bioavailability by genetic and proteolytic mechanisms. Journal of Biological Chemistry, December 1992, vol. 267, no. 36, p. 26031-26037.

KALKA, C.; TEHRANI, H.; LAUDENBERG, B.; VALE, P.R.; ISNER, J.M.; ASAHARA, T. and SYMES, J.F. VEGF gene transfer mobilizes endothelial progenitor cells in patients with inoperable coronary disease. Annals of Thoracic Surgery, September 2000, vol. 70, no. 3, p. 829834.

KLONER, R.A.; DOW, J.; CHUNG, G. and KEDES, L.H. Intramyocardial injection of DNA encoding vascular endothelial growth factor in a myocardial infarction model. Journal of Thrombosis and Thrombolysis, December 2000, vol. 10, no. 3, p. 285-289.

LEE, L.Y.; PATEL, S.R.; HACKETT, N.R.; MACK, C.A.; POLCE, D.R.; EL-SAWY, T.; HACHAMOVITCH, R.; ZANZONICO, P.; SANBORN, T.A.; PARIKH, M.; ISOM, O.W.; CRYSTAL, R.G. and ROSENGART, T.K. Focal angiogen therapy using intramyocardial delivery of an adenovirus vector coding for vascular endothelial growth factor 121. Annals of Thoracic Surgery, January 2000, vol. 69, no. 1, p. 14-23.

LEHRMAN, S. Virus treatment questioned after gene therapy death. Nature, October 1999, vol. 401, no. 6753, p. 517-518.

LEUNG, D.W.; CACHIANES, G.; KUANG, W.J.; GOEDDEL, D.V. and FERRARA, N. Vascular endothelial growth factor is a secreted angiogenic mitogen. Science, December 1989, vol. 246, no. 4935, p. 1306-1309.

LIBBY, P.; SCHWARTZ, D.; BROGI, E.; TANAKA, H. and CLINTON, S.K. A cascade model for restenosis. A special case of atherosclerosis progression. Circulation, December 1992, vol. 86, 6 Suppl, p. III47-III52.

LOPEZ, J.J.; LAHAM, R.J.; STAMLER, A.; PEARLMAN, J.D.; BUNTING, S.; KAPLAN, A.; CARROZZA, J.P.; SELLKE, F.W. and SIMONS, M. VEGF administration in chronic myocardial ischemia in pigs. Cardiovascular Research, November 1998, vol. 40, no. 2, p. 272-281.

LOSORDO, D.W.; VALE, P.R.; HENDEL, R.C.; MILLIKEN, C.E.; FORTUIN, F.D.; CUMMINGS, N.; SCHATZ, R.A.; ASAHARA, T.; ISNER, J.M. and KUNTZ, R.E. Phase 1/2 placebo-controlled, double-blind, dose-escalating trial of myocardial vascular endothelial growth factor 2 gene transfer by catheter delivery in patients with chronic myocardial ischemia. Circulation, April 2002, vol. 105, no. 17, p. 2012-2018.

LOSORDO, D.W.; PICKERING, J.G.; TAKESHITA, S.; LECLERC, G.; GAL, D.; WEIR, L.; KEARNEY, M.; JEKANOWSKI, J. and ISNER, J.M. Use of the rabbit ear artery to serially assess foreign protein secretion after sitespecific arterial gene transfer in vivo. Evidence that anatomic identification of successful gene transfer may underestimate the potential magnitude of transgene expression. Circulation, February 1994, vol. 89, no. 2, p. 785-792.

NABEL, G.J.; NABEL, E.G.; YANG, Z.Y.; FOX, B.A.; PLAUTZ, G.E.; GAO, X.; HUANG, L.; SHU, S.; GORDON, D. and CHANG, A.E. Direct gene transfer with DNA-liposome complexes in melanoma: expression, biologic activity, and lack of toxicity in humans. Proceedings of the National Academy of Sciences of the United States of America, December 1993, vol. 90, no. 23, p. 11307-11311.

NEUFELD, G.; COHEN, T.; GENGRINOVITCH, S. and POLTORAK, Z. Vascular endothelial growth factor (VEGF) and its receptors. FASEB Journal, January 1999, vol. 13, no. 1, p. 9-22.

OJALVO, A.G.; SERALENA, A.; VAZQUEZ, R.; MONTEQUIN, J.F.; VISPO, N.S.; SILVA, R.; ALDAMA, A.; PUCHADES, Y.; SORELL, L.T.; LOPEZ-SAURA, P.; 
ALFONSO, M.A.; SIMON, R.; ALI, A.; SEUC, A. and HERRERA, L. Therapeutic angiogenesis following intramuscular gene transfer of vascular endothelial growth factor 121 in a dog model of hindlimb ischemia. Electronic Journal of Biotechnology, [online]. 15 December 2003, vol. 6, no. 3, [cited 15 December 2003] . Available from Internet:

http://www.ejbiotechnology.info/content/vol6/issue3/full/2/ index.html. ISSN 07173458.

PATEL, S.R.; LEE, L.Y.; MACK, C.A.; POLCE, D.R.; EL-SAWY, T.; HACKETT, N.R.; ILERCIL, A.; JONES, E.C.; HAHN, R.T.; ISOM, O.W.; ROSENGART, T.K. and CRYSTAL, R.G. Safety of direct myocardial administration of an adenovirus vector encoding vascular endothelial growth factor 121. Human Gene Therapy, May 1999, vol. 10, no. 8, p. 1331-1348.

PLOUET, J.; MORO, F.; BERTAGNOLLI, S.; COLDEBOEUF, N.; MAZARGUIL, H.; CLAMENS, S. and BAYARD, F. Extracellular cleavage of the vascular endothelial growth factor 189-amino acid form by urokinase is required for its mitogenic effect. Journal of Biological Chemistry, May 1997, vol. 272, no. 20, p. 13390-13396.

ROSENGART, T.K.; LEE, L.Y.; PATEL, S.R.; SANBORN, T.A.; PARIKH, M.; BERGMAN, G.W.; HACHAMOVITCH, R.; SZULC, M.; KLIGFIELD, P.D.; OKIN, P.M.; HAHN, R.T.; DEVEREUX, R.B.; POST, M.R.; HACKETT, N.R.; FOSTER, T.; GRASSO, T.M.; LESSER, M.L.; ISOM, O.W. and CRYSTAL, R.G. Angiogenesis gene therapy: phase I assessment of direct intramyocardial administration of an adenovirus vector expressing $\mathrm{VEGF}_{121} \mathrm{cDNA}$ to individuals with clinically significant severe coronary artery disease. Circulation, August 1999a, vol. 100, no. 5, p. 468-474.

ROSENGART, T.K.; LEE, L.Y.; PATEL, S.R.; KLIGFIELD, P.D.; OKIN, P.M.; HACKETT, N.R.; ISOM, O.W. and CRYSTAL, R.G. Six-month assessment of a phase I trial of angiogenic gene therapy for the treatment of coronary artery disease using direct intramyocardial administration of an adenovirus vector expressing the $\mathrm{VEGF}_{121}$ cDNA. Annals of Surgery, October 1999b, vol. 230, no. 4, p. 466-470.

SCHWARZ, E.R.; SPEAKMAN, M.T.; PATTERSON, M.; HALE, S.S.; ISNER, J.M.; KEDES, L.H. and KLONER, R.A. Evaluation of the effects of intramyocardial injection of DNA expressing vascular endothelial growth factor (VEGF) in a myocardial infarction model in the ratangiogenesis and angioma formation. Journal of the American College of Cardiology, April 2000, vol. 35, no. 5, p. 1323-1330.
SYMES, J.F.; LOSORDO, D.W.; VALE, P.R.; LATHI, K.G.; ESAKOF, D.D.; MAYSKIY, M. and ISNER, J.M. Gene therapy with vascular endothelial growth factor for inoperable coronary artery disease. Annals of Thoracic Surgery, September 1999, vol. 68, no. 3, p. 830-836.

TAKESHITA, S.; ISSHIKI, T. and SATO, T. Increased expression of direct gene transfer into skeletal muscles observed after acute ischemic injury in rats. Laboratory Investigation, June 1996a, vol. 74, no. 6, p. 1061-1065.

TAKESHITA, S.; TSURUMI, Y.; COUFFINAHL, T.; ASAHARA, T.; BAUTERS, C.; SYMES, J.; FERRARA, N. and ISNER, J.M. Gene transfer of naked DNA encoding for three isoforms of vascular endothelial growth factor stimulates collateral development in vivo. Laboratory Investigation, October 1996b, vol. 75, no. 4, p. 487-501.

TIO, R.A.; TKEBUCHAVA, T.; SCHEUERMANN, T.H.; LEBHERZ, C.; MAGNER, M.; KEARNY, M.; ESAKOF, D.D.; ISNER, J.M. and SYMES, J.F. Intramyocardial gene therapy with naked DNA encoding vascular endothelial growth factor improves collateral flow to ischemic myocardium. Human Gene Therapy, December 1999, vol. 10, no. 18, p. 2953-2960.

VALE, P.R.; LOSORDO, D.W.; MILLIKEN, C.E.; MCDONALD, M.C.; GRAVELIN, L.M.; CURRY, C.M.; ESAKOF, D.D.; MAYSKY, M.; SYMES, J.F. and ISNER, J.M. Randomized, single-blind, placebo-controlled pilot study of catheter-based myocardial gene transfer for therapeutic angiogenesis using left ventricular electromechanical mapping in patients with chronic myocardial ischemia. Circulation, May 2001, vol. 103, no. 17, p. 2138-2143.

VALE, P.R.; LOSORDO, D.W.; MILLIKEN, C.E.; MAYSKY, M.; ESAKOF, D.D.; SYMES, J.F. and ISNER, J.M. Left ventricular electromechanical mapping to assess efficacy of phVEGF(165) gene transfer for therapeutic angiogenesis in chronic myocardial ischemia. Circulation, August 2000, vol. 102, no. 9, p. 965-974. 